\title{
Work-Life Conflict of Native and Immigrant Entrepreneurs in South Africa
}

\author{
Olawale Fatoki \\ Department of Business Management, University of Limpopo, South Africa \\ olawale.fatoki@ul.ac.za
}

\begin{abstract}
Work life conflict negatively impacts entrepreneurs and the economic performance of their businesses. The study explored the work-life conflict (WLC) of native and immigrant entrepreneurs in South Africa. Also, the study examined the effect of gender and work-related factors (long working hours and work overload) on the WLC of native and immigrant entrepreneurs. The study adopted the survey method (selfadministered questionnaires) for data collection. The participants in the study were identified through convenience and snowballing sampling methods. The methods of data analysis included descriptive statistics, T-test, Pearson correlation and regression analysis. The results showed high levels of WLC for both native and immigrant entrepreneurs. Native entrepreneurs have a higher level of WLC compared to immigrant entrepreneurs, however the difference is not statistically significant. Male entrepreneurs have a lower level of WLC compared to female entrepreneurs. Long working hours and work overload significantly impact on the WLC of native and immigrant entrepreneurs. Recommendations to reduce WLC include goal setting, scheduling and delegation of work by entrepreneurs.
\end{abstract}

Keywords: Work life conflict, native, immigrants, entrepreneurs, South Africa

\section{Introduction}

Small and medium enterprises (SMEs) contribute significantly to the economic growth of many countries including South Africa (Chinomona \& Pooe, 2013). SMEs help both developing and developed countries to sustain socio-economic development (Organisation for Economic Co-operation and Development, 2014). The contribution of SMEs to the gross domestic product of South Africa is between 27-34\%. In addition, 72\% of private sector jobs in South Africa is created by SMEs (Department of Trade and Industry, 2008). The unemployment rate in South Africa is very high and currently stands at $27.2 \%$. Furthermore, South Africa is confronted by high levels of income inequality, poverty and crime. The sustainability of SMEs can help to overcome the development challenges facing South Africa (Abor \& Quartey, 2010; Statistics South Africa, 2018). The small enterprise sector in South Africa includes both native and immigrant entrepreneurs. The motivation for entrepreneurship in South Africa is influenced by pulls and push factors. One of the push factors for entrepreneurship is work-life balance (Liedeman, Charman, Piper \& Petersen, 2013; Zimmerman \& Chu 2013; Charles \& Gherman, 2013). Conflicting work and family roles can be managed by selfemployment (Craig, Powell \& Cortis, 2012). Work-life balance (WLB) is one of the drivers of an entrepreneurial career (Nordenmark, Vinberg \& Strandh, 2012). WLB helps an individual to manage many role demands (Fleetwood, 2007). According to Annink, den Dulk \& Steijn, (2015), the combination of work, family and other individual responsibilities is an issue confronting many entrepreneurs. These different roles are not always mutually compatible and can lead to work-life conflict (WLC).

The term WLC is an opposite or a contradiction of WLB. WLC arises when the time and energy to satisfy one particular role make it difficult to achieve other roles. There is a significant negative relationship between WLC and individual and firm performance (Nadeem \& Abbas, 2009; Cegarra-Leiva, Sánchez-Vidal \& CegarraNavarro, 2012). This suggests that the reduction of WLC of employees and entrepreneurs can help to improve the performance and ultimately reduce the high failure rate of SMEs in South (Can't \& Wiid, 2013). Some empirical studies have addressed WLC in South Africa (Downes \& Koekemoer, 2011; Kotecha, Ukpere \& Geldenhuys, 2014). An exhaustive review of the literature by the researcher shows that no study has investigated empirically the WLC of both native and immigrant entrepreneurs. Also, the findings of studies on the effect of gender on WLC are inconclusive (Emslie \& Kunt, 2009). In addition, WLC is affected by both personal and work-related factors (Singh \& Kumar, 2011). The purpose of this study is to examine the WLC of native and immigrant entrepreneurs. Thus, care should be applied in generalising the findings of the study. Other studies can investigate the effect of WLC on the performance of native and immigrant entrepreneurs. In addition, the effect of family support on the WLC of female entrepreneurs can be examined. 


\section{Research Questions}

- What is the WLC of native and immigrant entrepreneurs?

- Is there a significant difference in the WLC of native and immigrant entrepreneurs?

- Is there a significant gender difference in the WLC of native and immigrant entrepreneurs?

- What is the relationship between work-related factors (long working hours and work overload) and the WLC of native and immigrant entrepreneurs?

\section{Literature Review}

Immigrant and Native Entrepreneur: Nieman \& Nieuwenhuizen, (2009) remark that an entrepreneur is an individual that identifies an opportunity, pulls resources together, and creates a sustainable business that meets the needs of customers. Small business owners are often called entrepreneurs (Lucky \& Olusegun, 2012). Both native and immigrant entrepreneurs operate in many countries. A native entrepreneur is an individual that was born in a country and starts a business in that particular country. An immigrant entrepreneur is an individual that arrives in another country from his country of birth and starts a business in the host country (Vinogradov, 2008). Both native and immigrant entrepreneurs contribute significantly to the economic development of host countries (Khosa \& Kalitanyi, 2014; Fatoki, 2015). The failure rates of businesses owned by native and immigrant entrepreneurs are very high. Native entrepreneurs are challenged by lack of management skills and inaccessibility to external finance (Cant \& Wiid, 2013). The challenges faced by immigrant entrepreneurs include language, xenophobia and inadequate access to finance (Liedeman et al. 2013; Chinomona \& Maziriri, 2015). Another problem that can impact on the performance of entrepreneurs and their organisations is WLC (Bell, Rajendran \& Theiler, 2012). This study will make a contribution to the literature on small business development and WLC from the context of native and immigrant entrepreneurs. The study is guided by the following research questions.

Definition of Work Life Conflict: Work life balance (WLB) can be regarded as the opposite of work life conflict (WLC) (Nadeem \& Abbas, 2009). The concept WLB has been labelled in the literature as workpersonal balance, work-family balance and work-family fit (Bell, Rajendran \& Theiler, 2012). However, because of the recognition that family is not the only important non-work function, the term WLB is generally used (Skinner \& Pocock, 2008; Bell et al. 2012). WLB has been defined in many ways by researchers (Kalliath \& Brough, 2008). Greenhaus, Collins \& Shaw (2003) and Greenhaus \& Allen (2011), describe WLB as the way an individual is involved and satisfied with his/her work and family role. Also, WLB can be positive or negative. A positive balance depicts high levels of satisfaction with work and non-work roles leading to WLB. A negative balance depicts low levels of satisfaction with work and non-work roles leading to WLC (Greenhaus et al. 2003; Carlson \& Grzywacz, 2008; Simmons, 2012). Frone, (2003) points out that WLC depicts a high level of inter-role conflict. Bell et al. (2012) refer to WLC as the conflict between work and personal or family roles. Individuals have many roles and WLC occurs when demands from one role interfere with other demands. Greenhous and Beutell, (1985) and Ahmad (2008) agree that WLC is caused by interrole conflict and can be time-based, stress-based and behaviour-based.

Theoretical Foundation of Work-Life Conflict: The concept of WLB can be explained theoretically by the Conflict Hypothesis by Goode, (1960), Role theory by Kahn, Wolfe, Quinn Snoek \& Rosenthal, (1964), the Enhancement Hypothesis (Marks, 1977; Sieber, 1974) and the Social Identity theory by Lobel, (1991). The Conflict Hypothesis argues that individuals have several roles with different demands. This can lead to conflict because of the limited resources and time to meet the demands. The Role theory postulates that interrole conflict is triggered by the expectations of the different roles performed by individuals. There is pressure on an individual to meet expectations from work, personal and family roles. The Enhancement Hypothesis contends that the multiple roles performed by an individual provide benefits such as security, privileges, personal growth and status. The Social Identity theory by Lobel, (1991) suggests that an individual can take part in numerous roles and reduce WLC by separating and managing the conflicting identities of these roles.

Work-Life Conflict of Native and Immigrant Entrepreneurs: A low level of WLC has many advantages for an entrepreneur. A low level of WLC can lead to increased well-being, decreased job stress and decreased burnout of employees, improved productivity and positive organisational performance. WLC can negatively 
impact on business performance. A high level of WLC is linked to lower organisational commitment, lower job satisfaction, lower career satisfaction and lower productivity and performance. WLC is one of the major stressors in the workplace (Bell et al. 2012; Annink et al. 2015). Chan (2008) establishes that immigrant entrepreneurs have to work long hours to be successful in host countries. Many immigrant entrepreneurs need to take care of family members in the home and host countries and this demands hard work (Forson, 2013). Hard work and long working hours are also critical to the survival and success of native entrepreneurs. Entrepreneurs are often addicted to their business and often find it difficult to meet other role demands (Gorgievski, Arnold \& Schaufeli, 2010; Antonites \& Govindasamy, 2013). This suggests that both native and immigrant entrepreneurs will experience high levels of WLC. It is hypothesised that there is no significant difference in the WLC of native and immigrant entrepreneurs.

Gender and Work-Life Conflict: Empirical findings of the effect of gender on WLC are inconclusive (Emslie \& Kunt, 2009). A study by Winslow, (2005) finds that there is no significant difference in the levels of WLC of males and females. Singh\& Kumar, (2011) reveal that female employees have higher levels of WLC compared to male employees. Women have more household responsibilities compared to men. Women retain the primary responsibility for home care (Emslie \& Kunt, 2009). WLB is not gender neutral. Female entrepreneurs often have to combine work with home and other responsibilities (Bianchi \& Milkie, 2010). It is hypothesised that there is a significant difference in the WLC of male and female entrepreneurs.

Determinants of Work-Life Conflict: Factors impacting on WLC can be examined from home and work perspectives. Home-related factors include the allocation of household chores and childcare. Work-related factors include long working hours and work overload (Singh \& Kumar, 2011).

Long Working Hours: Skinner \& Pocock (2008) remark that there is no generally accepted definition of long working hours in the literature. The meaning of long working hours differs across countries, industries and occupations. However, long working hours can be described as working more than 45 hours per week. In South Africa, Section 9 of the Basic Conditions of Employment Act that applies to employers and employees expects people to ordinarily work 45 hours per week (Government Gazette, 1997). However, passion for work is one of the attributes of an entrepreneur (Antonites \& Govindasamy, 2013). Self-employed individuals tend to work longer hours than employees (Gorgievskia et al. 2010). Long working hours may be incompatible with other life issues and can negatively affect the personal and social life of an entrepreneur (Annink et al. 2015). It is hypothesised that there is a significant positive relationship between long working hours and WLC.

Work Overload: Salam (2014) describes work overload as a situation where an employer or an employee has too many works to do with too little time. Many entrepreneurs are financially constrained and run their businesses without adequate human resources. This can lead to work overload (Kerr \& Nanda, 2009). There are many dimensions to work overload. These include time pressure, high speed of work and quantity of work (Skinner \& Pocock, 2008). Individuals with high workload are likely to experience fatigue and exhaustion. This may negatively affect the ability of such individuals to respond to other live domains (Razak, Yunus \& Nasurdin, 2011). It is hypothesised that there is a significant positive relationship between work overload and WLC.

\section{Research Methodology}

The study adopted the quantitative research approach. The survey method was used for data collection. The study area was the Central Business District of Johannesburg in the Gauteng province of South Africa. The study area contains a large number of native and immigrant entrepreneurs. The respondents were conveniently sampled because of the lack of a database of native and immigrant entrepreneurs in the study area. The study focused on entrepreneurs in the retail business. This helped to control for the influence of industry on WLC. The research instrument was pre-tested in a pilot study of twenty native and twenty immigrant entrepreneurs. This helped to improve face and content validity. Owners were assured of anonymity and confidentiality. The questionnaire was divided into four parts (1) biographical information (2) work-life conflict (3) long working hours and (4) work overload. The Cronbach's alpha was used as a measure 
of internal consistency. Descriptive statistics, T-test, Pearson Correlation and regression analysis were used for data analysis.

Operationalisation of Variables: Work life conflict: The researcher developed the questions to measure WLC from previous empirical studies (Konig et al. 2012; Nanda, 2015). The two studies measured WLC with high degrees of reliability as indicated by the Cronbach's alpha coefficients. The Cronbach's alpha coefficient of Konig et al. (2012) was 0.73 and that of Nanda, (2015) was 0.89. A five-point Likert scale ranging from ' 1 strongly disagrees to 5 strongly agree' was used to word the questions. WLC was measured by the following questions. (1) My job does not allow me to spend the amount of time that I like with my family, partner, spouse or other life activities. (2) My private life does not allow me to spend the amount of time that I like on my job. (3) I regularly think about the things that I need to do at work when I am at home (4) I often think about things that I need to do at home or other life activities when I am at work. The number of hours worked in a typical week was used to measure long working hours. The question items to measure long working hours included 'Working less than 45 hours (1), 45-54 hours (2) 55-64 hours (3), 65-74 hours in a week (4), 75-84 hours (5) 84-94 hours (6) above 94 hours' (7). This is consistent with the previous empirical literature on long working hours (Valcour, 2007; Annink et al. 2015). Work overload was measured by a 4-item scale the scale adopted from Thiagarajan, Chakrabarty \& Taylor, 2006). The scale by Thiagarajan et al. (2006) had a Cronbach's alpha was .89 and was a revision of an earlier 13-item scale by Reilly (1982). A five-point Likert scale ranging from ' $1=$ strongly disagree, to $5=$ strongly agree' was used. The question items were (1) I have to do things at work that I do not have the time and energy for (2) I need more hours at work every day to do all the things that are expected of me (3) I cannot seem to catch up with all the things that I need to do at work (4) I do not ever seem to have any time for myself. Razak, Yunus \& Nasurdin, (2011) and Taştan, (2014) also used a similar scale to measure work overload.

\section{Results and Discussion}

Biographical Details: Two hundred and fifty questionnaires were distributed to native entrepreneurs and one hundred and one questionnaires were returned. The response rate for native entrepreneurs was $40.4 \%$. For immigrant entrepreneurs, two hundred and fifty questionnaires were also distributed and one hundred and five questionnaires were returned. The response rate for immigrant entrepreneurs was $42 \%$.

Table 1: Biographical Information of the Respondents

\begin{tabular}{lll}
\hline Biographical characteristics & $\begin{array}{l}\text { Native } \\
\text { Frequency } \\
\text { (N=101) }\end{array}$ & $\begin{array}{l}\text { Immigrant } \\
\text { Frequency } \\
\text { (N=105) }\end{array}$ \\
\hline $\begin{array}{l}\text { Educational qualification of owner } \\
\text { Matric equivalent or below }\end{array}$ & 62 & 36 \\
$\begin{array}{l}\text { Post-Matric qualifications } \\
\text { Gender }\end{array}$ & 39 & 69 \\
Female & 43 & 39 \\
Male & 58 & 66 \\
Age of the owner (year) & & \\
Less than 20 & 0 & 2 \\
20-30 & 37 & 31 \\
$31-40$ & 49 & 65 \\
$41-50$ & 11 & 2 \\
Above 50 & 4 & 6 \\
Age of the firm (year) & & 54 \\
Less than one & 3 & 44 \\
1-5 & 38 & 1 \\
6-10 & 57 & 41 \\
Above ten years & 3 & 63 \\
\hline Number of employees & & \\
No employees & 28 & 65 \\
1-4 employees & & \\
\hline
\end{tabular}




\begin{tabular}{lll}
\hline $5-9$ employees & 8 & 1 \\
$10-49$ employees & 0 & 0 \\
$50-99$ employees & 0 & 0 \\
\hline
\end{tabular}

Table 1 shows that out of 102 native-owned businesses that participated in the survey, there were 58 males and 43 females. In addition, the majority of the participants have Matric or below qualifications, in the 31-40 age group and have been in operation for between six and ten years. In addition, the majority of the respondents have between one and four employees and can be classified as micro businesses. For immigrantowned businesses that participated in the survey, 69 males and 36 females participated in the survey. In addition, the majority of the respondents are males with post-matric qualifications. The majority of the respondents have been in business for1-5 years and are in the 31-40 age group. The majority of the participants in the study are micro-enterprises with between one and four employees.

Descriptive Statistics and T-Test Results: The section below shows the results of the descriptive statistics and the T-test for immigrant and native entrepreneurs.

\section{Comparison of Immigrant and Native Entrepreneurs}

Table 2: Descriptive Statistics and T-Test Results

\begin{tabular}{|c|c|c|c|c|c|c|c|}
\hline \multirow[t]{2}{*}{ WLB variables } & \multicolumn{2}{|l|}{ Immigrant } & \multicolumn{2}{|l|}{ Native } & \multirow[b]{2}{*}{$\mathbf{T}$} & \multirow[b]{2}{*}{ Df } & \multirow[b]{2}{*}{ Sig. } \\
\hline & Mean & $\begin{array}{l}\text { Standard } \\
\text { deviation }\end{array}$ & Mean & $\begin{array}{l}\text { Standard } \\
\text { deviation }\end{array}$ & & & \\
\hline $\begin{array}{l}\text { My job does not allow me } \\
\text { prevents me from spending } \\
\text { the amount of time that I like } \\
\text { with my partner, spouse or } \\
\text { family or other life activities }\end{array}$ & 3.76 & 0.984 & 4.12 & 0.974 & 2.720 & 9.01 & 0.522 \\
\hline $\begin{array}{l}\text { My private life does not } \\
\text { allow me to spend the } \\
\text { amount of time that I like on } \\
\text { my job. }\end{array}$ & 3.42 & 1.009 & 4.08 & 0.921 & 2.524 & 15.02 & 0.091 \\
\hline $\begin{array}{l}\text { I often think about the } \\
\text { things that I need to do at } \\
\text { work when I am at home }\end{array}$ & 3.65 & 1.002 & 4.03 & 0.944 & 2.111 & 11.04 & 0.240 \\
\hline $\begin{array}{l}\text { I often think about things } \\
\text { that I need to do at home or } \\
\text { other life activities when I } \\
\text { am at work }\end{array}$ & 3.80 & 1.010 & 3.86 & 1.024 & 1.997 & 13.06 & 0.680 \\
\hline Scale mean & 3.66 & 0.999 & 4.02 & 0.979 & 2.007 & 11.29 & 0.224 \\
\hline Cronbach's alpha & 0.744 & & 0.717 & & & & \\
\hline
\end{tabular}

Sig. $<0.05$

Table 2 shows the results of the descriptive statistics and independent samples T-test for the WLC of native and immigrant entrepreneurs. The scale means for immigrant and native entrepreneurs are 3.66 and 4.02 respectively. The Cronbach's alpha is 0.744 for immigrant entrepreneurs and 0.717 for native entrepreneurs indicating the reliability of the scale used to measure WLC. Both immigrant and native entrepreneurs have high levels of WLC as indicated by the means. The results also indicate that immigrant entrepreneurs $(3.84)$ have a slightly lower WLC compared to native entrepreneurs. However, the results of the T-test (T 2.007, df 11.29 sig. $=0.224$ ) does not indicate a significant difference in the WLC of immigrant and native entrepreneurs. The higher level of WLC of native entrepreneurs can be attributed to the effect of family and social interaction. The extended family of immigrant entrepreneurs may be in their host countries necessitating less family time. Immigrant entrepreneurs have fewer social links. The social integration of immigrant entrepreneurs in host countries takes time (Danes et al. 2008; Kushnirovich, 2016). The results indicate a significant positive relationship between long working hours and WLC for native and immigrant entrepreneurs. This suggests that long working hours can lead to WLC as there is little time for other 
activities. Individuals have many roles to play, such as an employer, manager, caregiver, parent, partner and child (Theiler, 2012).

Long Working Hours: However, long working hours can be described as working more 45 or more hours per week. Out of the 101 native entrepreneurs that participated in the study, 8 between work between 45-54 hours in a week, 31 work between 55-64 hours in a week, 60 work between 65-74 hours in a week and 2 work between 75-84 hours in a week. The results are consistent with the findings of Perks, (2010) and Mutyenyoka and Madzivhandila, (2014) that small business owners in South Africa work long hours. Out of 105 immigrant entrepreneurs that participated in the study, 4 work between 55-64 hours in a week 89 work between 65-74 hours in a week and 12 works for between 75-84 hours in a week. In addition, most of the immigrant entrepreneurs open for business on Sundays. Compared to salaried employees, entrepreneurs tend to work long hours and this may be incompatible with other life issues (Gorgievskia et al. 2014; (Annink et al. 2015).

\section{Gender Difference}

Table 3: Gender difference

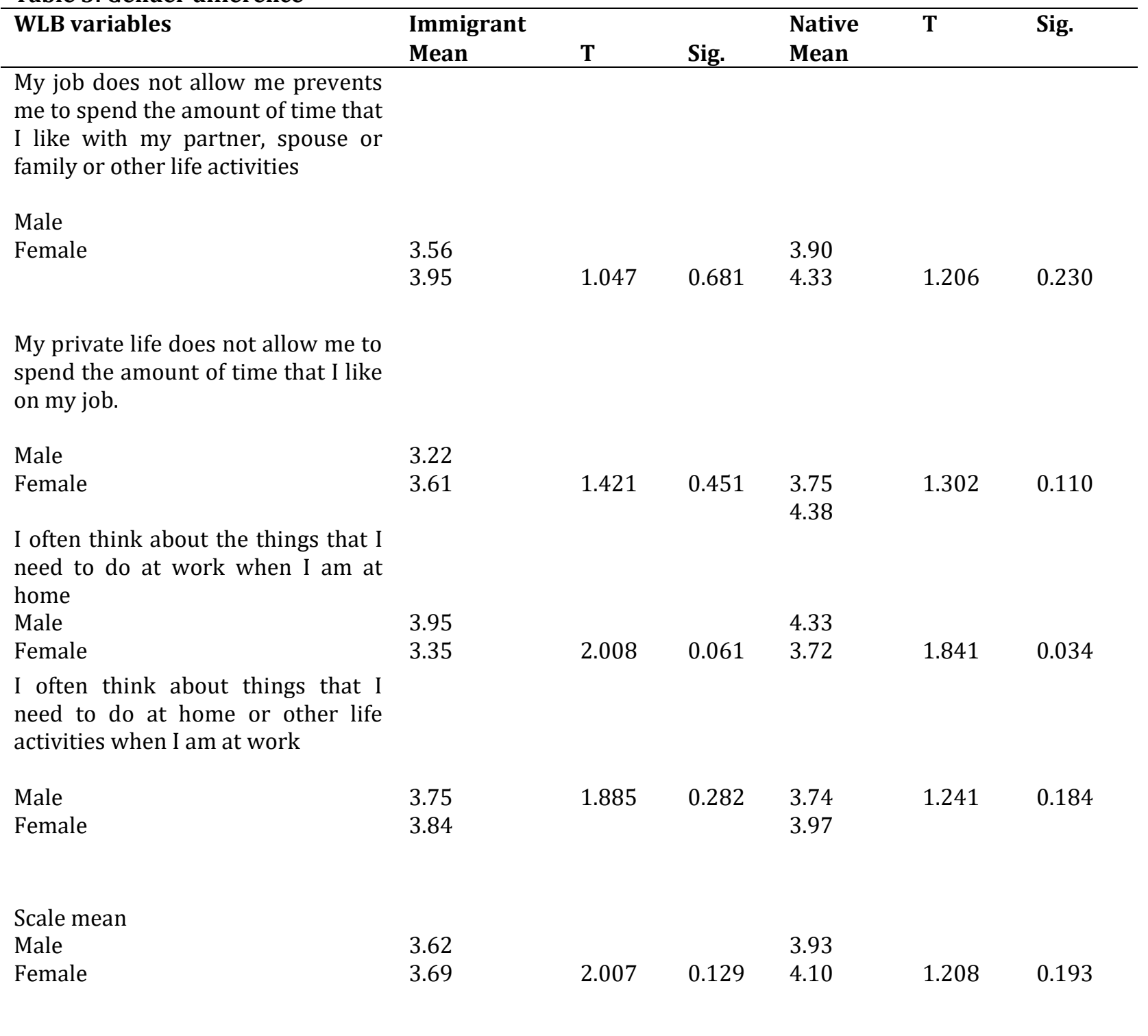

Sig., $<0.05$ 
The results as depicted in Table 3 indicate that females (scale mean 3.69) have a slightly higher level of WLC than males (scale mean 3.62) for immigrant entrepreneurs. For native entrepreneurs, females ((scale mean 4.10) have a higher WLC than males (scale mean 3.93). The T-test does not indicate a statistically significant difference between male and female respondents for both native and immigrant entrepreneurs. For the four measures of WLC, females have higher means than males in three. The only variables where males have a higher mean are the items "when I am at home, I often think about the things that I need to do at work". The T-test is statistically significant for this variable for native entrepreneurs. The results are consistent with the findings of Bianchi \& Milkie, (2010) that women have a higher level of WLC when compared to men.

Work Overload: The mean for work overload for a native entrepreneur is 3.84 and for immigrant entrepreneurs 3.64. The results indicate a higher level of work overload for native entrepreneurs compared to immigrant entrepreneurs. The Cronbach's alpha coefficients for native and immigrant entrepreneurs are 0.71 and 0.70 respectively indicating the internal consistency of measures. The T-test results $(t=8, d f 2.82$, sig. $=0.22$ ) does not indicate any significant difference in work overload of native and immigrant entrepreneurs. The results are consistent with the findings of Kalitanyi \& Visser, (2010) and Zhang, (2010) that immigrant entrepreneurs work long hours in host countries.

\section{Correlation and Regression Results}

Table 4: Correlation Results of Long Working Hours, Work Overload and WLC

\begin{tabular}{lllll}
\hline & $\begin{array}{l}\text { Native } \\
\text { entrepreneurs }\end{array}$ & \multicolumn{3}{l}{$\begin{array}{l}\text { Immigrant } \\
\text { entrepreneurs }\end{array}$} \\
Variable & R & Sig & R & Sig. \\
\hline Long working hours & 0.71 & 0.04 & 0.76 & 0.02 \\
Work overload & 0.69 & 0.01 & 0.71 & 0.04 \\
\hline
\end{tabular}

Sig. $<0.05$

Table 5: Regression Result of Long Working Hours and WLC Native entrepreneur

\begin{tabular}{|c|c|c|c|c|c|}
\hline \multirow[t]{2}{*}{ Model } & \multicolumn{2}{|c|}{ Unstandardized Coefficients } & \multirow{2}{*}{$\begin{array}{l}\text { Standardized } \\
\text { Coefficients } \\
\text { Beta }\end{array}$} & \multirow[t]{2}{*}{$\mathbf{T}$} & \multirow[t]{2}{*}{ Sig. } \\
\hline & B & Std. Error & & & \\
\hline Constant & 125.103 & 4.208 & & 1.428 & .000 \\
\hline $\begin{array}{l}\text { Long working } \\
\text { hours } \\
N=101, R=822, R\end{array}$ & square $=$ & sted R squar & $\begin{array}{l}.766 \\
\text { 1, Sig. } 0.05\end{array}$ & 10.305 & .000 \\
\hline \multicolumn{6}{|c|}{ Immigrant entrepreneur } \\
\hline \multirow[t]{2}{*}{ Model } & Unstand & oefficients & $\begin{array}{l}\text { Standardized } \\
\text { Coefficients }\end{array}$ & $\mathrm{T}$ & Sig. \\
\hline & B & Std. Error & Beta & & \\
\hline Constant & 108.111 & 3.041 & & 1.726 & .004 \\
\hline $\begin{array}{l}\text { Long working } \\
\text { hours } \\
N=105, \quad R=0.777\end{array}$ & 1.006 & usted R squ & 74. $\mathrm{Sig}<0.05$ & 10.008 & .000 \\
\hline
\end{tabular}

Sig $<0.05$ 
Table 6: Regression Result of Work Overload and WLC Native entrepreneur

\begin{tabular}{|c|c|c|c|c|c|}
\hline \multirow[t]{2}{*}{ Model } & \multicolumn{2}{|c|}{ Unstandardized Coefficients } & \multirow{2}{*}{$\begin{array}{l}\text { Standardized } \\
\text { Coefficients } \\
\text { Beta }\end{array}$} & \multirow[t]{2}{*}{$\mathbf{T}$} & \multirow[t]{2}{*}{ Sig. } \\
\hline & B & Std. Error & & & \\
\hline Constant & 102.008 & 3.401 & & 1.091 & .000 \\
\hline Work overload & 1.105 & .078 & .688 & 11.207 & .001 \\
\hline \multicolumn{6}{|c|}{$\begin{array}{l}\mathrm{N}=101, \mathrm{R}=.705, \mathrm{R} \text { square }=.648 \text {, Adjusted } \mathrm{R} \text { square }=.633 \text {, Sig. } 0.05 \\
\text { Immigrant entrepreneur }\end{array}$} \\
\hline \multirow[t]{2}{*}{ Model } & \multicolumn{2}{|c|}{ Unstandardized Coefficients } & $\begin{array}{l}\text { Standardized } \\
\text { Coefficients }\end{array}$ & $\mathrm{T}$ & Sig. \\
\hline & B & Std. Error & Beta & & \\
\hline Constant & 102.108 & 3.888 & & 1.726 & .002 \\
\hline Work overload & 1.241 & .0594 & .620 & 10.925 & .000 \\
\hline \multicolumn{6}{|c|}{$\mathrm{N}=105, \mathrm{R}=.701, \mathrm{R}$ square .624 , Adjusted $\mathrm{R}$ square $=.644$, Sig. $<0.05$} \\
\hline
\end{tabular}

The relationship between long working hours and WLC was examined using the Pearson correlation and regression. Tables 4, 5 and 6 summarise the results of correlation and regression for the WLC (dependent variable) and working long hours and work overload (independent variables). Long working hours: The results ( $r=0.71, n=101$, sig. $<0.05)$ for native entrepreneurs and ( $r=0.76, n=105$, sig. < 0.05) for immigrant entrepreneurs indicate a significant positive relationship between long working hours and WLC. For native entrepreneurs, the coefficient of determination R square is .714. This indicates that $70.4 \%$ of the variation in WLC is explained by long working hours.

The Beta is 0.766 and the level of significance is less than 0.05. For immigrant entrepreneurs (Rsquare $=0.688$, Beta $=0.682$, sig < 0.05). Passion for work is one of the attributes of an entrepreneur (Gorgievski et al. 2010; Antonites \& Govindasamy, 2013). Work overload: The results $(r=0.69, n=101$, sig $<0.05)$ for native entrepreneurs and $(\mathrm{r}=0.71, \mathrm{n}=105$. Sig<0.05) and regression ( $\mathrm{R}$ square .648 , Beta .688 , sig<0.05) for native entrepreneurs and (R square .624 , Beta .620 , sig<0.05) for immigrant entrepreneurs indicate a significant positive relationship between WLC and work overload. The high workload can contribute to feelings of exhaustion and strain. This may negatively affect the ability of such individuals to respond to other live domains (Skinner \& Pocock, 2008; Razak et al. 2011).

\section{Conclusion and Recommendations}

The study examined the WLC of native and immigrant entrepreneurs in South Africa. The study also investigated if there is a significant gender difference in the WLC of entrepreneurs. Furthermore, the study investigated the relationship between work-related factors (long working hours and work overload and WLC. The results indicated that both immigrant and native entrepreneurs have high levels of WLC. Immigrant entrepreneurs have a slightly lower WLC compared to native entrepreneurs. The higher level of WLC of native entrepreneurs can be attributed to the effect of family and social interaction. Native entrepreneurs often have kinships and extended family bonds. Compared to native entrepreneurs, immigrant entrepreneurs have fewer social links in host countries. The results indicated that male entrepreneurs have a lower level of WLC compared to female entrepreneurs. The results are not statistically significant. The results revealed a significant positive relationship between long working hours and WLC for native and immigrant entrepreneurs. The results also indicated a significant positive relationship between work overload and WLC for native and immigrant entrepreneurs. Individuals with high workload are likely to experience fatigue and exhaustion.

Recommendations and Areas for Further Study: WLC has to be managed by both native and immigrant entrepreneurs to improve performance. The findings of the study revealed high levels of WLC by both native 
and immigrant entrepreneurs. To manage WLC, both native and immigrant entrepreneurs should set goals that include both work and life activities. This can be achieved by the scheduling of work and life activities and the setting of realistic expectation of daily work achievement. This can also help to manage long working hours and work overload Organisations that support small business development in South Africa such as the Small Enterprise Development Agency should organise training on WLC for both native and immigrant entrepreneurs. The support of the family in reducing the WLC of women entrepreneurs is very important. Women entrepreneurs need to take a proactive approach to improve time management between work and family responsibilities. Training interventions aimed at reducing the high level of WLC of female entrepreneurs should be adopted by government agencies that support small businesses. The study focused on a relatively small sample of native and immigrant entrepreneurs. The bias of a limited number of respondents must be taken into account.

\section{References}

Abor, J. \& Quartey, P. (2010). Issues in SME Development in Ghana and South Africa. International Research Journal of Finance and Economics, 1(39), 218-228.

Ahmad, A. N. (2008). Dead men working: time and space in London's (illegal') migrant economy. Work, Employment \& Society, 22(2), 301-318.

Annink, A., den Dulk, L. \& Steijn, B. (2015). Work-family state support for the self-employed across Europe. Journal of Entrepreneurship and Public Policy, 4(2), 187-208.

Antonites, A. \& Govindasamy, T. (2013). Critical Success Factors of Indian Entrepreneurs. The Southern African Journal of Entrepreneurship and Small Business Management, 6, 115-133.

Bell, A. S., Rajendran, D. \& Theiler, S. (2012). Job stress, wellbeing, work-life balance and work-life conflict among Australian academics. Sensoria: A Journal of Mind, Brain \& Culture, 8(1), 25-37.

Bianchi, S. M. \& Milkie, M. A. (2010). Work and family research in the first decade of the 21st century. Journal of Marriage and Family, 72(3), 705-725.

Cant, M. C. \& Wiid, J. A. (2013). Establishing the Challenges Affecting South African SMEs. International Business \& Economics Research Journal, 12(6), 707-716.

Carlson, D. S. \& Grzywacz, J. G. (2008). Reflections and future directions on measurement in work-family research. In K. Korabik, D. S. Lero \& D. L. Whitehead (Eds.), Handbook of work-family integration: research, theory, and best practices, 57-73.

Cegarra-Leiva, D. Sánchez-Vidal, M. E. \& Cegarra-Navarro, J. (2012). Understanding the link between work-life balance practices and organisational outcomes in SMEs: The mediating effect of a supportive culture. Personnel Review, 41(3), 359-379.

Chan, C. (2008). Border crossing: work-life balance issues with Chinese entrepreneurs in New Zealand. Doctoral dissertation, Auckland University of Technology.

Charles, V. \& Gherman, T. (2013). Factors Influencing Peruvian Women to Become Entrepreneurs. World Applied Sciences Journal, 27(10), 1345-1354.

Chinomona, E. \& Maziriri, E. (2015). Examining the Phenomenon of Xenophobia as Experienced by African Immigrant Entrepreneurs in Johannesburg, South Africa: Intensifying the Spirit of "Ubuntu". International Journal of Research in Business Studies and Management, 2(6), 20-31.

Chinomona, R. \& Pooe, R. I. D. (2013). The Influence of Logistics Integration on Information Sharing and Business Performance: The Case of Small and Medium Enterprises in South Africa. Journal of Transport and Supply Chain Management, 7(1), 1-9.

Craig, L., Powell, A. \& Cortis, N. (2012). Self-employment, work-family time and the gender division of labor. Work, Employment \& Society, 26, 716-734.

Danes, S. M., Lee, J., Stafford, K. \& Heck, R. K. Z. (2008). The effects of ethnicity, families and culture on entrepreneurial experience: An extension of sustainable family business theory. Journal of Developmental Entrepreneurship, 13(03), 229-268.

Downes, C. \& Koekemoer, E. (2011). Work-life balance policies: Challenges and benefits associated with implementing flexitime. SA Journal of Human Resource Management, 9(1), 1-13.

Emslie, C. \& Hunt, K. (2009). Live to Work or 'Work to Live'? A Qualitative Study of Gender and Work-life Balance among Men and Women in Mid-life. Gender, Work \& Organization, 16(1), 151-172.

Fatoki, O. (2015). An Investigation into the Ethical Ideology of Immigrant Entrepreneurs in South Africa. Journal of Social Sciences, 43(2), 91-96. 
Fleetwood, S. (2007). Why work-life balance now? The International Journal of Human Resource Management, 18(3), 387-400.

Forson, C. (2013). Contextualising migrant black business women's work-life balance experiences. International Journal of Entrepreneurial Behaviour \& Research, 19(5), 460-477.

Frone, M. R. (2003). Work-family balance. In J. C. Quick \& L. E. Tetrick (Eds.), Handbook of occupational health psychology. Washington: American Psychological Association.

Goode, W. J. (1960). A theory of role strain. American Sociological Review, 25, 483-496.

Gorgievski, M. J., Arnold B. B. \& Schaufeli, W. B. (2010). Work engagement and work a holism: comparing the self-employed and salaried employees. The Journal of Positive Psychology, 5(1), 83-96.

Government Gazette. (1997). Basic Condition of Employment Act.

Government Gazette of the Republic of South Africa. (2003). National Small Business Amendment Act.

Greenhaus, J. \& Allen, T. (2011). Work-family balance: A review and extension of the literature. In J. C. Quick and L. E. Tetrick (Eds.), Handbook of occupational health psychology (2nd edition). Washington: American Psychological Association.

Greenhaus, J. H. \& Beutell, N. J. (1985). Sources of conflict between work and family roles. Academy of management review, 10(1), 76-88.

Greenhaus, J. H., Collins, K. M. \& Shaw, J. D. (2003). The relation between work-family balance and quality of life. Journal of Vocational Behavior, 63(3), 510-531.

Humbert, A. \& Drew, E. (2010). Gender, entrepreneurship and motivational factors in an Irish context. International Journal of Gender and Entrepreneurship, 2(2), 173-196.

Kahn, R. L., Wolfe, D. M., Quinn, R., Snoek, J. D. \& Rosenthal, R. A. (1964). Organizational stress: Studies in role conflict and ambiguity. New York: John Wiley \& Sons.

Kalitanyi, V. \& Visser, K. (2010). African immigrants in South Africa: job takers or job creators? South African Journal of Economic and Management Sciences, 13(4), 376-390.

Kalliath, T. \& Brough, P. (2008). Work-life balance: A review of the meaning of the balance construct. Journal of Management \& Organization, 14(3), 323-327.

Katua, N. T. (2014). The Role of SMEs in Employment Creation and Economic Growth in Selected Countries. International Journal of Education and Research, 2(12), 461-472.

Kerr, W. \& Nanda, R. (2009). Financing Constraints and Entrepreneurship.

Khosa, R. M. \& Kalitanyi, V. (2014). Challenges in operating micro-enterprises by African foreign entrepreneurs in Cape Town, South Africa. Mediterranean Journal of Social Sciences, 5(10), 205-215.

König, S., Langhauser, M., Cesinger, B. \& Leicht, R. (2012). Subjective Success in an Entrepreneurial CareerThe Case of Work-Life-Balance: Results from a Large-Scale Survey in Germany. Babson College Entrepreneurship Research Conference, Babson College, Wellesley.

Kotecha, K., Ukpere, W. \& Geldenhuys, M. (2014). The effect of family relationships on technology-assisted supplemental work and work-life conflict among academics. Mediterranean Journal of Social Sciences, 5(10), 516-527.

Kushnirovich, N. (2016). Economic Integration of Immigrant Entrepreneurs. Entrepreneurial Business and Economics Review, 3(3), 9-28.

Liedeman, R., Charman, A., Piper, L. \& Petersen, L. (2013). Why are foreign-run spaza shops more successful? The rapidly changing spaza sector in South Africa.

Lobel, S. A. (1991). Allocation of investment in work and family roles: Alternative theories and implications for research. Academy of Management Review, 16(3), 507-521.

Lucky, E. O. \& Olusegun, A. I. (2012). Is Small and Medium Enterprises (SMEs) an Entrepreneurship? International Journal of Academic Research in Business and Social Sciences, 2(1), 487-496.

Marks, S. R. (1977). Multiple roles and role strain: some notes on human energy, time and commitment. American Sociological Review, 42,921-936.

Mutyenyoka, E. M. \& Madzivhandila, T. S. (2014). Employment Creation through Small, Medium and Micro Enterprises (SMMEs) in South Africa: Challenges, Progress and Sustainability. Mediterranean Journal of Social Sciences, 5(25), 65-72.

Nadeem, M. S. \& Abbas, Q. (2009). The impact of work-life conflict on job satisfaction of employees in Pakistan. International Journal of Business and Management, 4(5), 63-83.

Nanda, A. (2015). Work life conflict: the spillover effect. International Journal of Research in Management and Business Studies, 2(1), 56-62.

Nieman, G. \& Nieuwenhuizen, C. (2009). Entrepreneurship: A South African Perspective. Van Schaik. 
Nordenmark, M., Vinberg, S. \& Strandh, M. (2012). Job control and demands, work-life balance and wellbeing among self-employed men and women in Europe. Vulnerable Groups and Inclusion, 3, 1-18.

Organisation for Economic Co-operation and Development. (2014). Financing SMEs and Entrepreneurs (2014).

Perks, S. (2010). Problem-solving techniques of growing very small businesses. Journal of Enterprising Communities: People and places in the global economy, 4(3), 220-233.

Razak, A. Z. A. A., Yunus, N. K. Y. \& Nasurdin, M. (2011). The impact of work overload and job involvement on work-family conflict among Malaysian doctors. Labuan e-Journal, 5, 1-10.

Reilly, M. D. (1982). Working wives and convenience consumption. Journal of consumer research, 4(8), 407418.

Salam, F. (2014). Work Overload, Work-Family Conflict, Family-Work Conflict and Their Effects on Job Embeddedness: The Moderating Role of Co-worker Support. Journal of Business and Management, 16(1), 75-80.

Sieber, S. D. (1974). Toward a theory of role accumulation. American Sociological Review, 39, 567-578.

Simmons, S. (2012). Striving for work-life balance. The American Journal of Nursing, 112(1), 25-26.

Singh, A. P. \& Kumar, A. (2011). Personality as a moderator between Stress State and Job Attitudes. Indian Journal of Social Science, 8 (1\&2), 149-158

Skinner, N. \& Pocock, B. (2008). Work-life conflict: Is work time or work overload more important. Asia Pacific Journal of Human Resources, 46(3), 303-315.

Statistics South Africa. (2018). Quarterly Labour Force Survey.

Taştan, S. B. (2014). Predicting Psychological Strain with Job Demands and Organizational Injustice through the Implications of Job Demand-Control Model and Fairness Theory. Postmodern Openings Deschideri Postmodern, 5(4), 111-143.

Thiagarajan, P., Chakrabarty, S. \& Taylor, R. D. (2006). A confirmatory factor analysis of Reilly's Role Overload Scale. Educational and psychological measurement, 66(4), 657-666.

Valcour, M. (2007). Work-based resources as moderators of the relationship between work hours and satisfaction with work-family balance. Journal of Applied Psychology, 92(6), 1512-1523.

Vinogradov, E. (2008). Immigrant entrepreneurship in Norway.

Winslow, S. (2005). Work-family conflict, gender, and parenthood. Journal of Family Issues, 26(6), 727-755.

Zhang, Z. (2010). The home country's role in shaping Chinese immigrant entrepreneurship. Doctoral dissertation, Auckland University of Technology.

Zimmerman, M. A. \& Chu, H. M. (2013). Motivation, Success, and Problems of Entrepreneurs in Venezuela. Journal of Management Policy and Practice, 14(2), 76-90. 